\title{
STUDI OPTIMASI DISTRIBUSI AIR IRIGASI PADA DAERAH IRIGASI TENGORO KABUPATEN BANYUWANGI DENGAN PROGRAM DINAMIK
}

\author{
Sari Nalurita ${ }^{1}$, Lily Montarcih L. ${ }^{2}$, Tri Budi Prayogo ${ }^{2}$ \\ ${ }^{1}$ Staf Bidang Operasi dan Pemeliharaan Dinas PU Pengairan Kabupaten Banyuwangi \\ ${ }^{2}$ Dosen Jurusan Teknik Pengairan Fakultas Teknik Universitas Brawijaya \\ Email: ieytha.nalurita@gmail.com
}

\begin{abstract}
ABSTRAK: Daerah irigasi Tengoro merupakan salah satu lokasi yang mengalami kendala dalam distribusi air irigasinya sehingga dilakukan upaya optimasi untuk mengkaji ulang agar tidak terjadi kekurangan air yaitu dengan menggunakan program dinamik stokastik. Sebelum optimasi, luas lahan yang dapat ditanami belum maksimal, dengan adanya optimasi maka luas lahan yang terairi meningkat untuk MH sebesar 20,84\% dan untuk MK 1 meningkat 0,85\%. Hal ini berdampak pula pada perolehan keuntungan dari hasil produksi dengan persentase peningkatan yang sama yaitu pada MH sebesar Rp 9.329.487.956,68 dan pada MK 1 sebesar Rp 8.143.711.211,34. Dari segi distribusi airnya, terjadi peningkatan efisiensi secara keseluruhan dari sebelum optimasi sebesar $86,52 \%$ menjadi sebesar $97,27 \%$.
\end{abstract}

Kata kunci: optimasi, irigasi, Tengoro, program dinamik, stokastik

\begin{abstract}
Tengoro irrigation area is one of the locations that have problems in the distribution of irrigation water due to the optimization efforts are to avoid water shortage by using stochastic dynamic program. Before optimization, extensive arable land is not maximized, with the optimization of the irrigated land area increased by 20,84\% on rainy season and during the first dry season increased to $0,85 \%$. This impacted on profitability of production by the same percentage increase that is at raiby season $R p$ 9.329.487.956,68 and at first dry season $R p$ 8.143.711.211,34. In terms of the distribution of water, an increase overall efficiency before optimization is $86,52 \%$ into $97,27 \%$.
\end{abstract}

Keywords: optimization, irrigation, Tengoro, dynamic programming, stochastic

Daerah irigasi Tengoro dengan baku sawah 1.074 ha yang terletak di desa Songgon kecamatan Songgon, kabupaten Banyuwangi. Wilayahnya berupa dataran tinggi yaitu pegunungan dengan hasil alam berupa produk perkebunan, dan dataran rendah yang memiliki beragam potensi produk hasil pertanian (banyuwangikab.go.id, 2016). Daerah irigasi Tengoro mengalami keterbatasan debit pada tiap musim mengakibatkan terjadi kekurangan air dalam beberapa periode musim tanam sehingga dilakukan upaya optimasi distribusi air irigasi. Salah satu model optimasi yang dapat digunakan adalah dengan program dinamik stokastik.
Tujuan dilakukan studi ini adalah untuk mengetahui bagaimana neraca air irigasi sebelum dan sesudah dilakukan optimasi, pola sebaran air optimal yang dapat memberikan keuntungan maksimal, serta tingkat efisiensi yang dicapai setelah diterapkan optimasi dengan program dinamik stokastik. Manfaat lain dari studi ini adalah agar bisa dijadikan bahan evaluasi dalam melaksanakan pembagian air irigasi di daerah irigasi Tengoro.

\section{BAHAN DAN METODE}

Data-data yang diperlukan dalam studi ini meliputi data sekunder terkait dengan analisis optimasi distribusi air irigasi: 
1. Data Debit

Data debit yang digunakan adalah data debit intake dam Tengoro 10 tahun terakhir yang dimulai dari tahun 2006 sampai tahun 2015.

2. Data Rencana Tata Tanam Global (RTTG) Data RTTG yang digunakan adalah RTTG tahun 2015/2016. RTTG akan memberikan gambaran yang jelas mengenai luas area lokasi studi, pola tata tanam (jenis tanaman yang diterapkan), sehingga dapat diketahui kebutuhan air irigasi.

3. Skema Daerah Irigasi

Data Skema daerah irigasi ini digunakan untuk mengetahui luas lahan pertanian yang akan diairi.

4. Data Biaya Produksi Tanaman Padi dan Palawija

Data biaya produksi tanaman padi dan palawija yang dipakai adalah data tahun 2016, digunakan untuk mengetahui berapa besar manfaat irigasi yang selanjutnya digunakan untuk menghitung keuntungan tiap tanaman dalam musim tanam tertentu.

Metode analisis yang digunakan adalah dengan program dinamik stokastik tipe no. 1, dimana sifat acak terjadi menurut return ditentukan secara unik oleh state-state, tetapi state-state yang diakibatkan oleh satu atau lebih keputusan bersifat tidak pasti (Limantara, 2010) dengan langkah pengolahan data sebagai berikut.

1. Menghitung kebutuhan air irigasi dengan metode LPR-FPR sesuai dengan pola tata tanam dan masa tanam yang tercantum pada RTTG 2015-2016.

Dalam menghitung kebutuhan air pada daerah irigasi berdasarkan kebutuhan air Polowijo Relatif dengan penjelasan berikut (DPU Pengairan Prov. Jatim, 2013):

LPR $=($ Luas tanam $) \times($ koef. tanam $)$

Debit yang dibutuhkan pada pintu tersier adalah LPR pada petak tersier tersebut dikalikan dengan FPR, yaitu kebutuhan air untuk polowijo.

$\mathrm{Q}=\quad$ LPR $\times$ FPR

dimana:

$\mathrm{Q}=$ Debit Rencana (lt/dt)

$\mathrm{LPR}=$ Luas Polowijo Relatif rencana

(ha pol)

FPR = Faktor-Polowijo-Relatif rencana (lt/dt/ha pol )

2. Perhitungan neraca air untuk mengetahui apakah debit yang tersedia dapat mencukupi debit yang dibutuhkan.
3. Pengolahan data debit menjadi volume yang terbagi menjadi volume tersedia dan volume kebutuhan irigasi yang kemudian dilakukan uji kesesuaian data untuk dihitung sebaran probabilitasnya.

4. Perhitungan optimasi dengan program dinamik stokastik sehingga diperoleh keuntungan maksimum dengan jalur yang optimal.

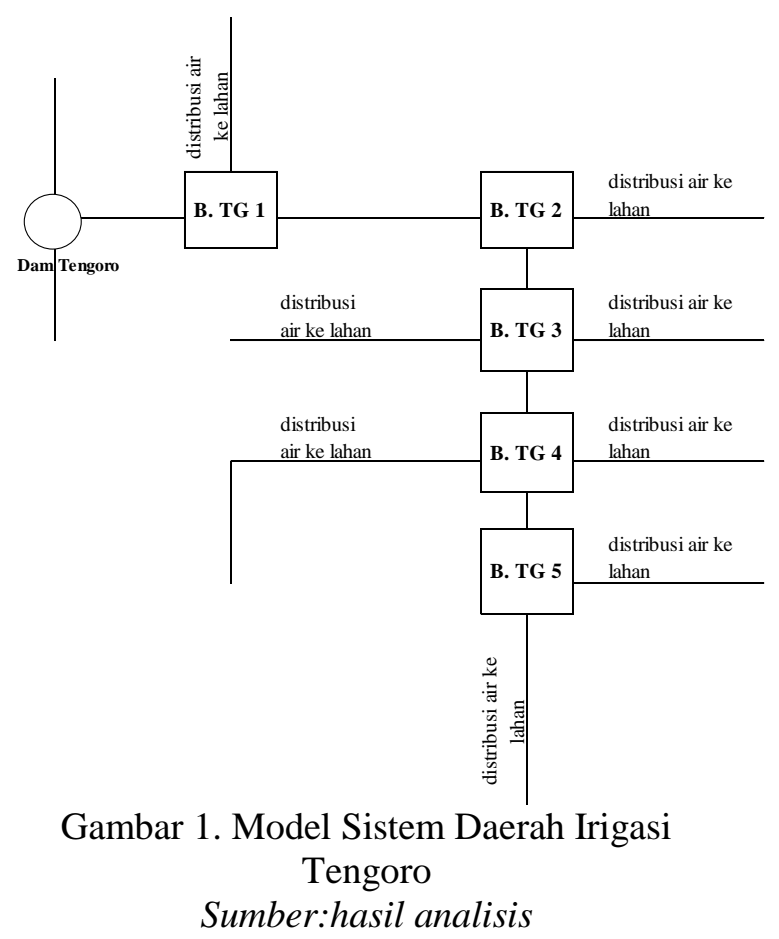

Prosedur penyelesaian optimasi alokasi air dengan program dinamik stokastik pada daerah irigasi Tengoro dilakukan sebagai berikut:

1. Menghitung besarnya volume air yang dibutuhkan untuk tiap bangunan irigasi yang akan dikaji.

2. Menghitung besar volume air yang tersedia dari debit andalan yang dialirkan secara terus menerus.

3. Dari volume yang dibutuhkan dan volume yang tersedia, dihitung luas lahan yang terairi oleh debit yang ada pada tiap periode tanam pada tiap bangunan irigasi.

4. Menentukan keuntungan yang merupakan keuntungan bersih dari debit yang dialirkan pada tiap bangunan irigasi.

5. Keuntungan didapatkan dari perhitungan biaya produksi tanaman per hektar dan harga jual serta produktivitas tanaman.

6. Melakukan uji kesesuaian distribusi data selisih antara volume ketersediaan dan 
volume kebutuhan dengan uji SmirnovKolmogorof dan uji Chi-Square

7. Menentukan probabilitas kebutuhan air dengan pendekatan sebaran probabilitas berdasarkan distribusi Log Pearson III.

8. Melakukan perhitungan tabel Expected Value dengan kisaran tertentu untuk tiap musim tanam MH, MK 1, dan MK 2

9. Selanjutnya dengna nilai-nilai pada tabel Expected Value, dilakukan prosedur recursive sepbagaimana pada program dinamik deterministik.

Penyelesaian program dinamik stokastik pada dasarnya dengan mentransformasikan proses stokastik menjadi deterministik. Hal ini dilakukan dengan membuat tabel Expected Value (EV) yang berisi nilai akibat tahap (stage return) sebagai fungsi dari decision variable (variable keputusan). Secara umum bentuk dari tabel EV untuk program dinamik dengan $n$ tahap dan variable keputusan dalam kisaran $\mathrm{x}_{1}$ sampai $\mathrm{x}_{\mathrm{m}}$, sebagai berikut (Limantara \& Soetopo, 2011).

Tabel 1. Bentuk Tabel Expected Value

\begin{tabular}{|c|c|c|c|c|c|}
\hline & \multicolumn{5}{|c|}{ Nilai alokasi tahap untuk variabel keputusan $\mathrm{xj}$} \\
\hline & $\mathrm{xl}$ & $\mathrm{x} 2$ & $\mathrm{x} 3$ & $\mathrm{x} 4$ & $\mathrm{xm}$ \\
\hline Fungsi tahap $1(x)$ & $\mathrm{Fl}(\mathrm{xl})$ & $\mathrm{Fl}(\mathrm{x} 2)$ & $\mathrm{Fl}(\mathrm{x} 3)$ & $\mathrm{Fl}(\mathrm{x} 4)$ & $\mathrm{Fl}(\mathrm{xm})$ \\
\hline Fungsi tahap 2(x) & $\mathrm{F} 2(\mathrm{xl})$ & $\mathrm{F} 2(\mathrm{x} 2)$ & $\mathrm{F} 2(\mathrm{x} 3)$ & $\mathrm{F} 2(\mathrm{x} 4)$ & $\mathrm{F} 2(\mathrm{xm})$ \\
\hline Fungsi tahap 3(x) & $\mathrm{F} 3(\mathrm{xl})$ & $\mathrm{F} 3(\mathrm{x} 2)$ & $\mathrm{F} 3\left(\mathrm{x}_{3}\right)$ & $\mathrm{F} 3(\mathrm{x} 4)$ & $\mathrm{F} 3(\mathrm{xm})$ \\
\hline Fungsi tahap $\mathrm{n}(\mathrm{x})$ & $\mathrm{Fn}(\mathrm{xl})$ & $\mathrm{Fn}(\mathrm{x} 2)$ & $\mathrm{Fn}\left(\mathrm{x}_{3}\right)$ & $\mathrm{Fn}(\mathrm{x} 4)$ & $\mathrm{Fn}(\mathrm{xm})$ \\
\hline
\end{tabular}

Sumber: Limantara \& Soetopo, 2011

Jadi $\mathrm{F}_{\mathrm{n}}\left(\mathrm{x}_{\mathrm{m}}\right)$ merupakan nilai akibat tahap ke-n untuk pengambilan keputusan sebesar $\mathrm{x}_{\mathrm{j}}$, maka untuk menghitung setiap nilai $\mathrm{F}_{\mathrm{i}}\left(\mathrm{x}_{\mathrm{j}}\right)$ digunakan konsep expected value. Apabila semua $\mathrm{F}_{\mathrm{i}}\left(\mathrm{x}_{\mathrm{j}}\right)$ pada tabel expected value selesai dihitung, maka nilai-nilai akibat tahap dapat dianggap deterministik. Sehingga dengan menggunakan tabel expected value tersebut, selanjutnya dapat dilakukan perhitungan optimasi dengan prosedur recursive sebagaimana pada program dinamik deterministik (Limantara \& Soetopo, 2011).

10. Pada prosedur recursive, hasil dari tahap pertama ditransformasikan ke tahap berikutnya, demikian sampai tahap akhir.

11. Dengan pelacakan balik (back tracking), akan diperoleh jalur dengan nilai maksimum.

12. Keuntungan maksimum pada tahap akhir merupakan nilai rerata keuntungan apabila kebijakan alokasi optimal tersebut diterapkan dalam jangka panjang.

\section{HASIL DAN PEMBAHASAN}

Dari hasil perhitungan kebutuhan air irigasi sesuai dengan RTTG 2015/2016, dapat dilihat dari neraca berikut bahwa masih terjadi kekurangan air pada beberapa periode tanam tertentu yang dapat dilihat pada gambar 2 .

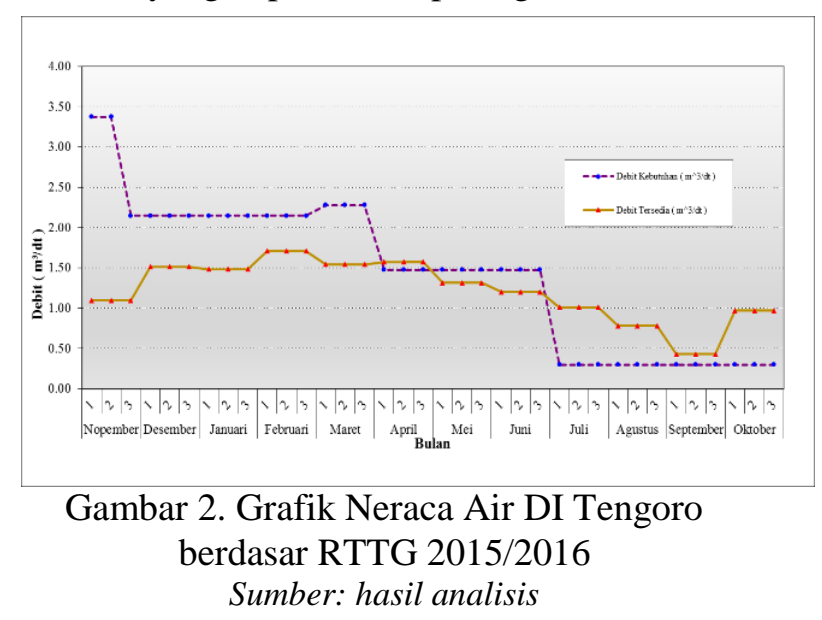

Oleh karena itu dilakukan upaya optimasi pada saat musim tanam MH dan MK 1 dimana pada dua musim tanam tersebut terdapat kekurangan air. Optimasi dilakukan dengan terlebih dahulu menentukan sebaran probabilitas dari seisih antara ketersediaan air dengan kebutuhan air yang diwujudkan dalam bentuk unit volume dimana 1 unit volume air mewakili $1.000 .000 \mathrm{~m}^{3}$ volume air.

Tabel 2. Perhitungan volume air yang dibutuhkan tiap bangunan irigasi pada saat $\mathrm{MH}$

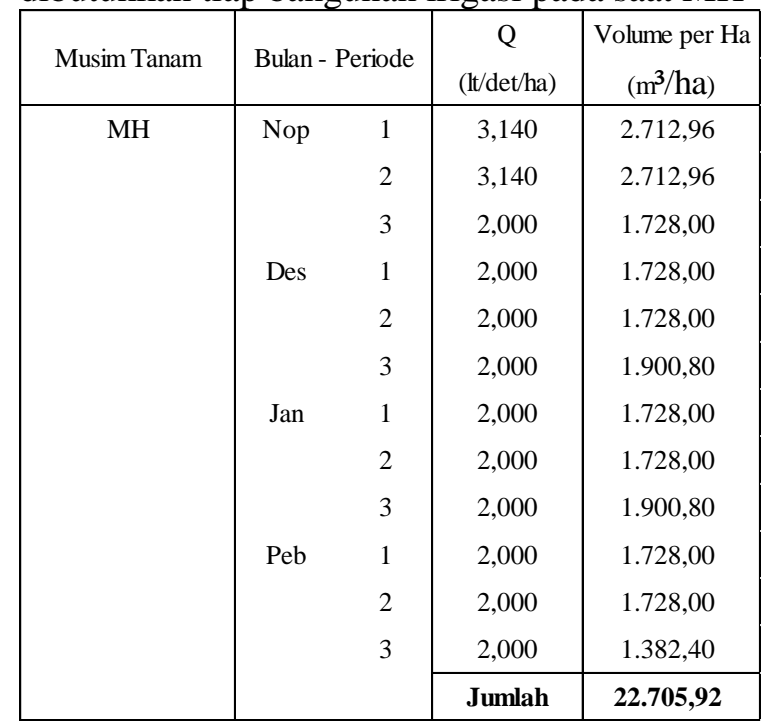

Sumber: hasil analisis 
Untuk menghitung volume air yang dibutuhkan pada satu periode tanam dilakukan dengan menjumlahkan volume tiap 10 harian selama satu periode tanam tersebut. Dalam studi ini, besar volume air yang dibutuhkan untuk tiap bangunan irigasi pada daerah irigasi Tengoro adalah sama karena perhitungan kebutuhan air irigasi dilakukan secara global.

Tabel 3. Perhitungan volume air yang dibutuhkan tiap bangunan irigasi pada saat MK1

\begin{tabular}{|c|c|c|c|c|}
\hline Musim Tanam & \multicolumn{2}{|c|}{ Bulan - Periode } & $\begin{array}{c}\mathrm{Q} \\
\text { (lt/det/ha) }\end{array}$ & $\begin{array}{c}\text { Volume per Ha } \\
\left(\mathrm{m}^{3} / \mathrm{ha}\right)\end{array}$ \\
\hline \multirow[t]{13}{*}{ MK 1} & \multirow[t]{3}{*}{ Mar } & 1 & 2,123 & $1.834,22$ \\
\hline & & 2 & 2,123 & $1.834,22$ \\
\hline & & 3 & 2,123 & $2.017,64$ \\
\hline & \multirow[t]{3}{*}{ Apr } & 1 & 1,374 & $1.187,26$ \\
\hline & & 2 & 1,374 & $1.187,26$ \\
\hline & & 3 & 1,374 & $1.187,26$ \\
\hline & \multirow[t]{3}{*}{ Mei } & 1 & 1,374 & $1.187,26$ \\
\hline & & 2 & 1,374 & $1.187,26$ \\
\hline & & 3 & 1,374 & $1.305,99$ \\
\hline & \multirow[t]{4}{*}{ Jun } & 1 & 1,374 & $1.187,26$ \\
\hline & & 2 & 1,374 & $1.187,26$ \\
\hline & & \multirow[t]{2}{*}{3} & 1,374 & $1.187,26$ \\
\hline & & & Jumlah & $16.490,18$ \\
\hline
\end{tabular}

Sumber: hasil analisis

Data debit intake historik yang digunakan adalah data debit bulanan yang masuk ke dalam sistem jaringan irigasi pada daerah irigasi Tengoro. Data debit intake historik yang tersedia seluruhnya sepanjang 10 tahun (2006 s/d 2015). Dari data debit intake dikurangi dengan debit kebutuhan diuji untuk mencari sebaran yang sesuai, dengan menggunakan uji Chi-Square dan uji Smirnov-Kolmogorov.

Chi-Square dilakukan untuk mengetahui apakah persamaan distribusi peluang terpilih dapat mewakili distribusi statistik sampel data yang dianalisis, agar distribusi yang dipilih bisa ditetapkan maka : $\mathrm{X}^{2}$ hitung $<\mathrm{X}^{2}$ kritis

Prosedur uji Chi-Square adalah :

1. Urutkan data pengamatan (diurutkan dari nilai terbesar ke terkecil atau sebaliknya)

2. Kelompokkan data menjadi $\mathrm{G}$ kelas

3. $\mathrm{k}=1+3,22 \log \mathrm{n}$

$$
=1+3,22 \log 10
$$$$
=4,22
$$

Sehingga dapat dibuat menjadi 4 kelas dengan interval peluang masing-masing kelas :

Kelas $1=\mathrm{P} \leq 0,25$

Kelas $2=\mathrm{P} \leq 0,50$
Kelas $3=\mathrm{P} \leq 0,75$

Kelas $4=\mathrm{P}>0,75$

Menetukan persamaan garis lurus berdasarkan persamaan umum garis lurus yang digunakan (Soewarno, 1995):

$$
\mathrm{X}=\mathrm{X}+\mathrm{k} \cdot \mathrm{S}
$$

Dimana :

$\mathrm{X}=$ Perkiraan nilai yang diharapkan terjadi dengan besar peluang tertentu.

$X=$ nilai rata-rata hitung

$\mathrm{S}=$ deviasi standar

$\mathrm{K}$ = faktor frekuensi

4. Jumlahkan data pengamatan sebesar Oi tiap-tiap kelas

5. Jumlahkan data dari persamaan distribusi yang digunakan sebesar Ei

6. Tiap-tiap kelas hitung nilai (Oi-Ei)2 dan

7. Jumlah seluruh $G$ kelas nilai untuk menentukan nilai $\mathrm{X}^{2}$ hitung.

Uji kecocokan Smirnov Kolmogorov atau sering disebut sebagai uji kecocokan non parametrik, karena tidak menggunakan distribusi tertentu dalam proses pengujiannya.

Langkah perhitungannya adalah :

1. Urutkan data (dari nilai terbesar menuju nilai terkecil atau sebaliknya) dan menentukan besar peluang dari tiap nilai data tersebut.

2. Tentukan nilai $\log \mathrm{Xi}$ dari masing-masing data tersebut.

3. Tentukan nilai masing-masing peluang pengamatan Pe.

Dari kedua nilai peluang yang diperoleh, dihitung selisih terbesarnya antara nilai peluang pengamatan dengan nilai peluang teoritis.

4. Tentukan nilai masing-masing peluang teoritis G.

5. Berdasarkan tabel nilai kritis untuk uji Smirnov Kolmogorov tentukan harga $\Delta \mathrm{P}$. Apabila $\Delta$ Pmax lebih kecil dari $\Delta$ Pcr maka distribusi teorotis yang digunakan untuk mendapatkan persamaan distribusi dapat diterima.

Pada kedua uji memperlihatkan bahwa distribusi peluang yang digunakan dapat mewakili dari distribusi stastistik data yang dianalisis. Untuk itu distribusi Log Pearson III dapat dipakai dalam proses optimasi stokastik untuk mencari sebaran probabilitasnya. 


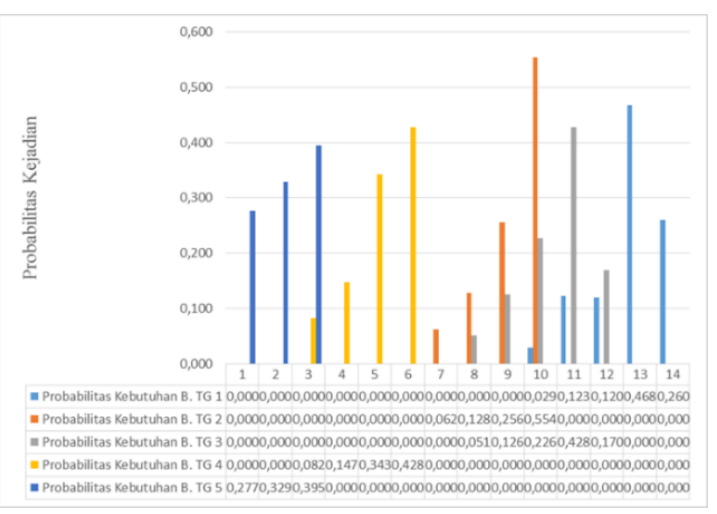

Gambar 3. Diagram Sebaran Probabilitas

Kebutuhan Air pada saat MH

Sumber: hasil analisis

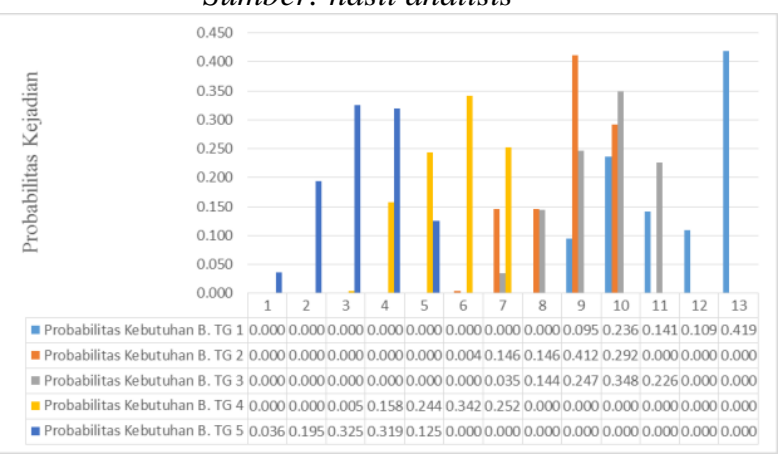

Gambar 4. Diagram Sebaran Probabilitas

Kebutuhan Air pada saat MK 1

Sumber: hasil analisis

Dengan mengacu pada RTTG 2015-2016, maka optimasi dilakukan pada DI. Tengoro dengan menerapkan pola tata tanam yang sama yaitu:

- Musim hujan (MH) $\rightarrow$ padi $100 \%$.

- Musim kemarau 1 (MK 1) $\rightarrow$ padi $(84,45 \%)$ - palawija $(15,55 \%)$.

- Musim kemarau 2 (MK 2) $\rightarrow$ palawija $100 \%$.

- Awal masa tanam yaitu bulan nopember periode 1 .

Dalam studi ini, diasumsikan bahwa:

a. Apabila alokasi air melebihi kebutuhan, maka kelebihan air akan terbuang begitu saja untuk kemudian dimanfaatkan oleh daerah irigasi dibawahnya.

b. Apabila alokasi air di bawah kebutuhan, maka hanya air alokasi tersebut yang akan dimanfaatkan dan mendatangkan keuntungan, dengan catatan bahwa alokasi tidak melebihi batasan luas lahan yang terairi di tiap bangunan baginya.

Dalam model program dinamik stokastik tipe no. 1 ini, ditentukan beberapa hal sebagai berikut:

1. Terdapat 5 (lima) tahap (stage) yaitu B. TG $1-$ B. TG 5
2. Variabel Keputusan adalah alokasi $x$ dengan kisaran 0 sampai dengan 12 untuk MH dan 11 untuk MK 1

Lalu dilakukan perhitungan tabel Expected value, yaitu isi tabel $\mathrm{Fi}(\mathrm{x})$, dengan kisaran $\mathrm{i}=1$ s/d 12 untuk MH dan 1 s/d 11 untuk MK 1 serta $\mathrm{x}=0 \mathrm{~s} / \mathrm{d} 12$ untuk $\mathrm{MH}$ dan $0 \mathrm{~s} / \mathrm{d} 11$ untuk MK 1. Misal untuk F4 $(x=3)$ pada saat $M H$ yang berarti alokasi ke B. TG 4 sebesar 3 unit volume air, maka perhitungan diuraikan dalam tabel berikut.

Tabel 4. Perhitungan nilai F4( $\mathrm{x}=3)$ saat $\mathrm{MH}$

\begin{tabular}{|c|c|c|c|c|c|}
\hline $\begin{array}{c}\text { Kebutuhan } \\
\text { (Unit Volume Air) }\end{array}$ & \begin{tabular}{|c|} 
Probabilitas \\
$\mathrm{pi}$
\end{tabular} & $\begin{array}{c}\text { Alokasi } \\
\text { (Lnit Volume Air) }\end{array}$ & $\begin{array}{c}\text { Keuntungan } \\
\text { (Luit Volume Air) }\end{array}$ & $\begin{array}{l}\text { Keuntungan } \\
\text { Vi(npiah) }\end{array}$ & $\begin{array}{l}\text { pix Vi } \\
\text { (rupah) }\end{array}$ \\
\hline 1 & 0.000 & 3 & 1 & $817,541,207.10$ & 0.00 \\
\hline 2 & 0.000 & 3 & 2 & $1,635,082,414.20$ & 0.00 \\
\hline 3 & 0.082 & 3 & 3 & $2,452,623,621.30$ & $201,778,414.89$ \\
\hline 4 & 0.147 & 3 & 3 & $2,452,623,621.30$ & $360,587,190.81$ \\
\hline 5 & 0.343 & 3 & 3 & $2,452,623,621.30$ & $840,616,320.46$ \\
\hline 6 & 0.428 & 3 & 3 & $2,452,623,621.30$ & $1,049,641,695.14$ \\
\hline 7 & 0.000 & 3 & 3 & $2,452,623,621.30$ & 0.00 \\
\hline 8 & 0.000 & 3 & 3 & $2,452,623,621.30$ & 0.00 \\
\hline 9 & 0.000 & 3 & 3 & $2,452,623,621.30$ & 0.00 \\
\hline 10 & 0.000 & 3 & 3 & $2,452,623,621.30$ & 0.00 \\
\hline 11 & 0.000 & 3 & 3 & $2,452,623,621.30$ & 0.00 \\
\hline 12 & 0.000 & 3 & 3 & $2,452,623,621.30$ & 0.00 \\
\hline 13 & 0.000 & 3 & 3 & $2,452,623,621.30$ & 0.00 \\
\hline 14 & 0.000 & 3 & 3 & $2,452,623,621.30$ & 0.00 \\
\hline & & & & $F 4(3)=$ & $2,452,623,62130$ \\
\hline
\end{tabular}

Sumber: hasil analisis

Penjelasan:

Kolom 1 : tabel sebaran probabilitas

Kolom 2 : tabel sebaran probabilitas

Kolom 3 : alokasi $=\mathrm{x}=3$ unit volume air ke B. TG 4

Kolom 4 : keuntungan (unit volume air) yang terkecil antara kebutuhan dan alokasi

Kolom 5 : keuntungan dalam rupiah = keuntungan (unit volume air) $\mathrm{x}$ keuntungan (rupiah).

Tabel 5. Tabel expected value pada saat MH

\begin{tabular}{|c|c|c|c|c|c|}
\hline untuk $\mathrm{x}=$ & $\mathrm{F} 1(\mathrm{x})$ & $\mathrm{F} 2(\mathrm{x})$ & $\mathrm{F} 3(\mathrm{x})$ & $\mathrm{F} 4(\mathrm{x})$ & $\mathrm{F} 5(\mathrm{x})$ \\
\hline 0 & 0,00 & 0,00 & 0,00 & 0,00 & 0,00 \\
\hline 1 & $40.444 .200,00$ & $817.541 .207,10$ & $817.541 .207,10$ & $817.541 .207,10$ & $817.541 .207,10$ \\
\hline 2 & $40.444 .200,00$ & $1.635 .082 .414,20$ & $1.635 .082 .414,20$ & $1.635 .082 .414,20$ & $1.408 .790 .559,21$ \\
\hline 3 & $40.444 .200,00$ & $2.452 .623 .621,30$ & $1.635 .082 .414,20$ & $2.452 .623 .621,30$ & $1.731 .335 .162,95$ \\
\hline 4 & $40.444 .200,00$ & $2.452 .623 .621,30$ & $1.635 .082 .414,20$ & $3.202 .905 .356,77$ & $1.731 .335 .162,95$ \\
\hline 5 & $40.444 .200,00$ & $2.452 .623 .621,30$ & $1.635 .082 .414,20$ & $3.832 .991 .361,97$ & $1.731 .335 .162,95$ \\
\hline 6 & $40.444 .200,00$ & $2.452 .623 .621,30$ & $1.635 .082 .414,20$ & $4.182 .871 .927,02$ & $1.731 .335 .162,95$ \\
\hline 7 & $40.444 .200,00$ & $2.452 .623 .621,30$ & $1.635 .082 .414,20$ & $4.182 .871 .927,02$ & $1.731 .335 .162,95$ \\
\hline 8 & $40.444 .200,00$ & $2.452 .623 .621,30$ & $1.635 .082 .414,20$ & $4.182 .871 .927,02$ & $1.731 .335 .162,95$ \\
\hline 9 & $40.444 .200,00$ & $2.452 .623 .621,30$ & $1.635 .082 .414,20$ & $4.182 .871 .927,02$ & $1.731 .335 .162,95$ \\
\hline 10 & $40.444 .200,00$ & $2.452 .623 .621,30$ & $1.635 .082 .414,20$ & $4.182 .871 .927,02$ & $1.731 .335 .162,95$ \\
\hline 11 & $40.444 .200,00$ & $2.452 .623 .621,30$ & $1.635 .082 .414,20$ & $4.182 .871 .927,02$ & $1.731 .335 .162,95$ \\
\hline 12 & $40.444 .200,00$ & $2.452 .623 .621,30$ & $1.635 .082 .414,20$ & $4.182 .871 .927,02$ & $1.731 .335 .162,95$ \\
\hline
\end{tabular}

Sumber: hasil analisis 
Tabel 6. Tabel expected value pada saat MK 1

\begin{tabular}{|c|c|c|c|c|c|}
\hline untuk $x=$ & $F 1(\mathrm{x})$ & $\mathrm{F} 2(\mathrm{x})$ & $\mathrm{F} 3(\mathrm{x})$ & $\mathrm{F} 4(\mathrm{x})$ & $\mathrm{F} 5(\mathrm{x})$ \\
\hline 0 & 0,00 & 0,00 & 0,00 & 0,00 & 0,00 \\
\hline 1 & $36.760 .357,26$ & $743.075 .814,33$ & $743.075 .814,33$ & $743.075 .814,33$ & $743.075 .814,33$ \\
\hline 2 & $36.760 .357,26$ & $1.486 .151 .628,66$ & $1.486 .151 .628,66$ & $1.486 .151 .628,66$ & $1.459 .553 .480,20$ \\
\hline 3 & $36.760 .357,26$ & $2.229 .227 .442,98$ & $1.486 .151 .628,66$ & $2.229 .227 .442,98$ & $2.031 .394 .883,23$ \\
\hline 4 & $36.760 .357,26$ & $2.229 .227 .442,98$ & $1.486 .151 .628,66$ & $2.968 .778 .659,50$ & $2.361 .390 .666,39$ \\
\hline 5 & $36.760 .357,26$ & $2.229 .227 .442,98$ & $1.486 .151 .628,66$ & $3.590 .991 .309,46$ & $2.454 .467 .336,79$ \\
\hline 6 & $36.760 .357,26$ & $2.229 .227 .442,98$ & $1.486 .151 .628,66$ & $4.032 .198 .946,38$ & $2.454 .467 .336,79$ \\
\hline 7 & $36.760 .357,26$ & $2.229 .227 .442,98$ & $1.486 .151 .628,66$ & $4.032 .198 .946,38$ & $2.454 .467 .336,79$ \\
\hline 8 & $36.760 .357,26$ & $2.229 .227 .442,98$ & $1.486 .151 .628,66$ & $4.032 .198 .946,38$ & $2.454 .467 .336,79$ \\
\hline 9 & $36.760 .357,26$ & $2.229 .227 .442,98$ & $1.486 .151 .628,66$ & $4.032 .198 .946,38$ & $2.454 .467 .336,79$ \\
\hline 10 & $36.760 .357,26$ & $2.229 .227 .442,98$ & $1.486 .151 .628,66$ & $4.032 .198 .946,38$ & $2.454 .467 .336,79$ \\
\hline 11 & $36.760 .357,26$ & $2.229 .227 .442,98$ & $1.486 .151 .628,66$ & $4.032 .198 .946,38$ & $2.454 .467 .336,79$ \\
\hline
\end{tabular}

Sumber: hasil analisis

Setelah dilakukan optimasi dengan program dinamik stokastik maka didapakan hasil sebagai berikut.

Tabel 7. Perbandingan Hasil Optimasi dengan Program Dinamik Stokastik

\begin{tabular}{|c|c|c|c|c|c|c|c|}
\hline \multirow{2}{*}{\begin{tabular}{|l} 
Musim \\
Tanam
\end{tabular}} & \multicolumn{2}{|c|}{ Keuntungan (Rp) } & \multicolumn{2}{|c|}{ Luas lahan yang terairi (ha) } & \multicolumn{2}{|c|}{ Volume air irigasi (unit) } & \multirow{2}{*}{$\begin{array}{c}\text { Volume } \\
\text { tersedia (unit }\end{array}$} \\
\hline & sebelum & setelah & sebelum & setelah & sebelum & setelah & \\
\hline MH & $7.384 .760 .034,25$ & $9.329 .487 .956,68$ & 547,77 & 692,03 & 9,03 & 11,41 & 12,00 \\
\hline MK 1 & $8.074 .397 .3355,52$ & $8.143 .711 .211,34$ & 658,95 & 664,61 & 10,87 & 10,96 & 11,00 \\
\hline Jumlah & 15.459.157.369,76 & $17.473 .199 .168,02$ & & & 19,90 & 22,37 & 23,00 \\
\hline & & & Efisien & gasi $(\%)$ & 86,52 & 97,27 & \\
\hline
\end{tabular}

Sumber: hasil analisis

Terlihat bahwa untuk musim tanam $\mathrm{MH}$ dan MK 1 terjadi peningkatan keuntungan dan pemanfaatan air irigasi lebih optimal. Sedangkan untuk efisiensi irigasi yang dicapai sebelum optimasi sebesar $86,52 \%$ meningkat setelah optimasi menjadi 97,27\%. Dengan kata lain prosentase pemakaian air setelah optimasi terhadap pemakaian air sebelum optimasi yaitu sebesar 98,88\%.

Dari tabel di atas, setelah didapatkan keuntungan, luas lahan dan banyaknya air yang digunakan pada tiap musim tanam, maka diuraikan menjadi per bangunan bagi menjadi sebagai berikut.

Tabel 8. Pola Sebaran Air untuk Mendapatkan Keuntungan Maksimal MH

\begin{tabular}{|l|c|c|c|c|c|c|c|c|}
\hline \multirow{2}{*}{ Bangunan } & \multicolumn{2}{|c|}{ Luas terairi (ha) } & \multicolumn{2}{|c|}{ Intensitas Tanam $(\%)$} & \multicolumn{2}{c|}{$\begin{array}{c}\text { Kebutuhan air } \\
\text { irigasi (m/d) }\end{array}$} & \multicolumn{2}{c|}{ Keuntungan (Rp) } \\
\cline { 2 - 10 } & sebelum & setelah & sebelum & setelah & sebelum & setelah & sebelum & setelah \\
\hline B. TG 1 & 3,00 & 0,00 & 0,28 & 0,00 & 0,006 & 0,000 & $40.444 .200,00$ & 0,00 \\
\hline B. TG 2 & 149,00 & 149,00 & 13,87 & 13,87 & 0,316 & 0,386 & $2.008 .728 .600,00$ & $2.452 .623 .621,30$ \\
\hline B. TG 3 & 100,00 & 100,00 & 9,31 & 9,31 & 0,212 & 0,257 & $1.348 .140 .000,00$ & $1.635 .082 .414,20$ \\
\hline B. TG 4 & 295,77 & 303,21 & 27,54 & 28,23 & 0,627 & 0,603 & $3.987 .447 .234,25$ & $3.832 .991 .361,97$ \\
\hline B. TG 5 & 0,00 & 139,82 & 0,00 & 13,02 & 0,000 & 0,297 & 0,00 & $1.408 .790 .559,21$ \\
\hline Jumlah & 547,77 & 692,03 & 51,00 & 64,43 & 1,162 & 1,542 & $7.384 .760 .034,25$ & $9.329 .487 .956,68$ \\
\hline
\end{tabular}

Sumber: hasil analisis
Dapat dilihat pada saat MH dari tabel di atas, terjadi peningkatan luas lahan, intensitas tanam serta keuntungan menyeluruh. Akan tetapi ada kalanya luas lahan tetap namun keuntungan yang dihasilkan meningkat sebagaimana yang terjadi di B.TG 2 dan B.TG 3. Hal ini karena adanya pengaruh nilai probabilitas yang mengakibatkan peningkatan alokasi air (lebih detailnya dapat dilihat pada tabel EV) sehingga mengakibatkan nilai keuntungan meningkat.

Tabel 9. Pola Sebaran Air untuk Mendapatkan Keuntungan Maksimal MK 1

\begin{tabular}{|l|c|c|c|c|c|c|c|c|}
\hline \multirow{2}{*}{ Bangunan } & \multicolumn{2}{|c|}{ Luas terairi (ha) } & \multicolumn{2}{|c|}{ Intensitas Tanam (\%) } & \multicolumn{2}{c|}{$\begin{array}{c}\text { Kebutuhan air } \\
\text { irigasi (m/dt) }\end{array}$} & \multicolumn{2}{c|}{ Keuntungan (Rp) } \\
\cline { 2 - 9 } & sebelum & setelah & sebelum & setelah & sebelum & setelah & sebelum & setelah \\
\hline B. TG 1 & 3,00 & 0,00 & 0,28 & 0,00 & 0,006 & 0,000 & $36.760 .357,26$ & 0,00 \\
\hline B. TG 2 & 149,00 & 149,00 & 13,87 & 13,87 & 0,316 & 0,386 & $1.825 .764 .410,71$ & $2.229 .227 .442,98$ \\
\hline B. TG 3 & 100,00 & 100,00 & 9,31 & 9,31 & 0,212 & 0,257 & $1.225 .345 .242,09$ & $1.486 .151 .628,66$ \\
\hline B. TG 4 & 338,00 & 242,57 & 31,47 & 22,59 & 0,717 & 0,514 & $4.141 .666 .918,25$ & $2.968 .778 .659,50$ \\
\hline B. TG 5 & 68,95 & 173,04 & 6,42 & 16,11 & 0,146 & 0,253 & $844.860 .407,21$ & $1.459 .553 .480,20$ \\
\hline Jumlah & 658,95 & 664,61 & 61,35 & 61,88 & 1,397 & 1,409 & $8.074 .397 .335,52$ & $8.143 .711 .211,34$ \\
\hline
\end{tabular}

Sumber: hasil analisis

Untuk hasil yang didapat pada tabel di atas, tidak jauh beda dengan saat $\mathrm{MH}$, terjadi peningkatan luas lahan yang ditanami, intensitas tanam serta keuntungan menyeluruh. Untuk keuntungan yang meningkat dari luas lahan yang sama juga dipengaruhi oleh nilai probabilitas yang mengakibatkan peningkatan alokasi air (lebih detailnya dapat dilihat pada tabel EV).

Dari hasil tersebut, dengan luasan maksimal yang dapat diairi, maka dapat dihitung kebutuhan air irigasinya sehingga didapatkan neraca air setelah dilakukan optimasi dengan program dinamik stokastik sebagai berikut.

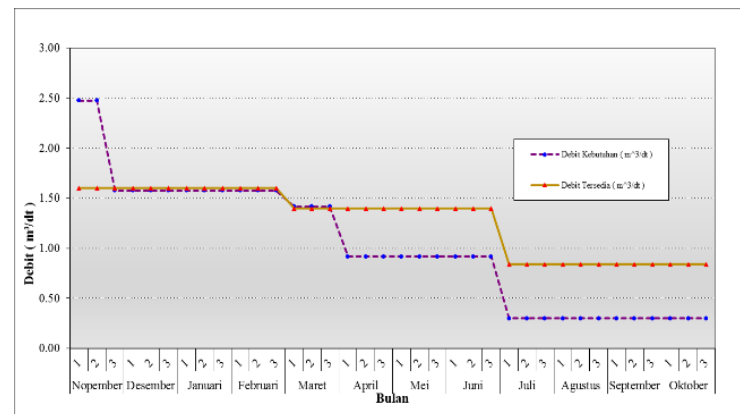

Gambar 5. Grafik Neraca Air setelah Optimasi Sumber: hasil analisis

Terlihat bahwa setelah dilakukan optimasi, masih terjadi kekurangan air untuk beberapa periode, terutama pada awal masa tanam MH dan MK 1. Hal ini terjadi dikarenakan pada awal musim tanam 
merupakan masa pembibitan dan garap tanah yang memang memerlukan air lebih banyak dari pada saat masa pertumbuhan tanaman.

\section{KESIMPULAN}

Berdasarkan pembahasan yang telah dilakukan pada bab sebelumnya dan berlandaskan pada rumusan masalah, maka dapat diambil kesimpulan sebagai berikut:

1. Pada neraca air dapat dilihat bahwa dengan pola tanam yang sama, sebelumnya terjadi kekurangan air yang cukup banyak pada saat $\mathrm{MH}$ dan $\mathrm{MK}$ 1, setelah dilakukan optimasi dengan program dinamik stokastik kebutuhan air irigasi dapat dipenuhi dengan optimal meskipun masih ada kekurangan pada periode 1 dan 2 awal masa tanam $\mathrm{MH}$ dan periode 1-3 awal masa tanam MK 1. Hal ini dikarenakan kebutuhan air untuk masa pembibitan dan garap tanah tanaman padi yang membutuhkan air lebih banyak dari masa pertumbuhannya.

2. Dengan menerapkan program dinamik stokastik, dapat diketahui pola sebaran air saat $\mathrm{MH}$ di B. TG 1 sebesar 0,000 m3/det, B. TG 2 sebesar $0,386 \mathrm{~m} 3 /$ det, B. TG 3 sebesar 0,257 m3/det, B. TG 4 sebesar $0,603 \mathrm{~m} 3 /$ det, dan B. TG 5 sebesar 0,297 m3/det dengan jumlah total 1,542 m3/det dari yang sebelumnya $1,162 \mathrm{~m} 3 /$ det. Pada saat MK 1 di B. TG 1 sebesar 0,000 m3/det, B. TG 2 sebesar $0,386 \mathrm{~m} 3 /$ det, B. TG 3 sebesar 0,257 m3/det, B. TG 4 sebesar $0,514 \mathrm{~m} 3 /$ det, dan B. TG 5 sebesar 0,253 m3/det dengan jumlah total 1,409 m3/det dari yang sebelumnya $1,397 \mathrm{~m} 3 /$ det.

3. Tingkat efisiensi irigasi secara keseluruhan meningkat dari sebelum optimasi yaitu sebesar $86,52 \%$ setelah dilakukan optimasi dengan program dinamik stokastik menjadi sebesar 97,27\%. Dengan kata lain prosentase pemakaian air setelah optimasi terhadap pemakaian air sebelum optimasi yaitu sebesar 98,88\%.

4. Keuntungan maksimal yang didapatkan dari ketersediaan air yang ada pada $\mathrm{MH}$ sebesar Rp 9.329.487.956,68 (meningkat 20,84\% dari sebelum optimasi), pada MK 1 sebesar Rp 8.143.711.211,34 (meningkat 0,85\% dari sebelum optimasi)

\section{DAFTAR PUSTAKA}

Pemkab Banyuwangi. Website Resmi Pemerintah Kabupaten Banyuwangi. http://banyuwangikab.go.id (diakses : 20 Januari, 2016).

DPU Pengairan Provinsi Jawa Timur. 2013. Pedoman Operasi Pemeliharaan Jaringan Irigasi. Surabaya.

Limantara, Lily M. 2010. Hidrologi Praktis. Bandung: CV. Lubuk Agung.

Limantara, Lily M. \& Soetopo, Widandi. 2011. Manajemen Sumber Daya Air. Bandung: CV. Lubuk Agung.

Soewarno. 1995. Hidrologi - Aplikasi Metode Statistik untuk Analisa Data Jilid 2. Bandung: Nova. 